\title{
Thermal behavior of Sr-form of gordaite
}

\section{Термично поведение на $\mathrm{Sr}$ форма на гордаит}

\author{
Zlatka Delcheva $^{1}$, Tsveta Staminirova ${ }^{2}$, Nadia Petrova ${ }^{1}$ \\ Златка Делчева ${ }^{1}$ Цвета Станимирова ${ }^{2}$, Надя Петрова ${ }^{1}$ \\ ${ }^{1}$ Institute of Mineralogy and Crystallography, Bulgarian Academy of Sciences, 107 Acad. G. Bonchev Str., 1113 Sofia; \\ E-mail: zlatka.delcheva.1989@gmail.com \\ ${ }^{2}$ University of Sofia “St. Kliment Ohridski”, Faculty of Geology and Geography, Department of Mineralogy, Petrology \\ and Economic Geology, 15 Tzar Osvoboditel Blvd., 1000 Sofia
}

\begin{abstract}
Cation-exchanged Sr-form of gordaite was successfully obtained from Ca-form of gordaite by an ionexchange reaction. Data of XRD, SEM-EDS and DTA-TG-MS were used to characterize the Sr-form. Thermal decomposition of Sr-gordaite was studied for the first time in regards of thermal events and mass loss during volatile releasing. It was found similarity with Sr-gordaite and Ca-gordaite in terms of processes, type, and amount of volatiles released, but also some differences were found concerning the temperature correspondence of the volatiles evolving and the type of thermal decomposition products. The influence of the exchangeable cations $(\mathrm{Na}, \mathrm{Ca}, \mathrm{or} \mathrm{Sr})$ on the dehydration of the interlayer in the gordaite type structure were also established.
\end{abstract}

Keywords: Sr-gordaite, thermal behavior, decomposition products.

\section{Introduction}

Zn-hydroxy-sulfate minerals as part of the minerals hydroxy-salts of various divalent cations such as $\mathrm{Cu}, \mathrm{Fe}$, $\mathrm{Ni}, \mathrm{Co}, \mathrm{Cd}$ structurally belong to the group of layered hydroxy-salt compounds. They are an important part of the development of sulfide deposits under epithermal conditions (Sillitoe, 2005). Apart from being part of the oxidation zones of sulfide deposits, zinc hydroxy salts are also found in workout mining and tailings ponds, because of the alkalization of mining wastewater. In this way, they play an important ecological role, preventing the migration of toxic $\mathrm{Zn}$ ions into the environment.

On the other hand, zinc hydroxy salts are one of the main phases in the patina of zinc and brass materials. The excellent resistance of brass, zinc, and galvanized steel under natural conditions is due to the formation of a protective corrosion layer of zinc hydroxy salts (zinc rust), the mineral composition of which depends on the influence of the environment. The protective effect of the corrosion layer depends on the composition, morphology, and location of the crystals, as well as on the processes of thermal decomposition - dehydration, dehydroxylation, and separation of other volatile components.

In turn, interest in the processes and products of thermal decomposition of Zn-hydroxy-sulfate minerals in the last few decades has been provoked by several specific properties. The thermal products are important components for the hydrometallurgy of zinc and lead (Bear et al., 1986, 1987); indicators for corrosion stability (Santana et al., 2012); precursors for obtaining micro- and nanosized $\mathrm{ZnO}$ for various applications - catalysis, photoluminescence, ceramics, etc. (Moezzi et al., 2013).

In the present work, the object of study is cationic forms of the Zn-hydroxy-sulfate mineral, named gordaite. The gordaite structure is composed of negative charged octahedral-tetrahedral hydroxide layers $\left[\mathrm{Zn}_{6}{ }^{\text {oct }} \square^{\text {oct }}(\mathrm{OH})_{6}\right.$ $\left.\left(\mathrm{SO}_{4}\right)_{2} \mathrm{Zn}_{2}{ }^{\text {tetr }}(\mathrm{OH})_{6} \mathrm{Cl}_{2}\right]^{2-}$. The charge is compensated by exchangeable cation-water complexes $\left[\mathrm{Na}\left(\mathrm{H}_{2} \mathrm{O}\right)_{6}\right]^{+}$, located in the interlayer space (Adiwidjaja et al., 1997). There are data in the literature on the products and processes of thermal decomposition of some gordaites (Stanimirova et al., 2016; Maruyama et al., 2017), but there are no data on the influence of exchangeable cations on the thermal behavior of compounds with gordaite type structure.

The present study aims to obtain an ion-exchange $\mathrm{Sr}$ form of gordaite and to study its thermal behavior in the context of the thermal behavior of other exchangeable forms $(\mathrm{Ca}, \mathrm{Na})$ of gordaite.

\section{Experimental}

The Sr-form of gordaite was successfully obtained from the Ca-form by an ion-exchange reaction. The cation- 


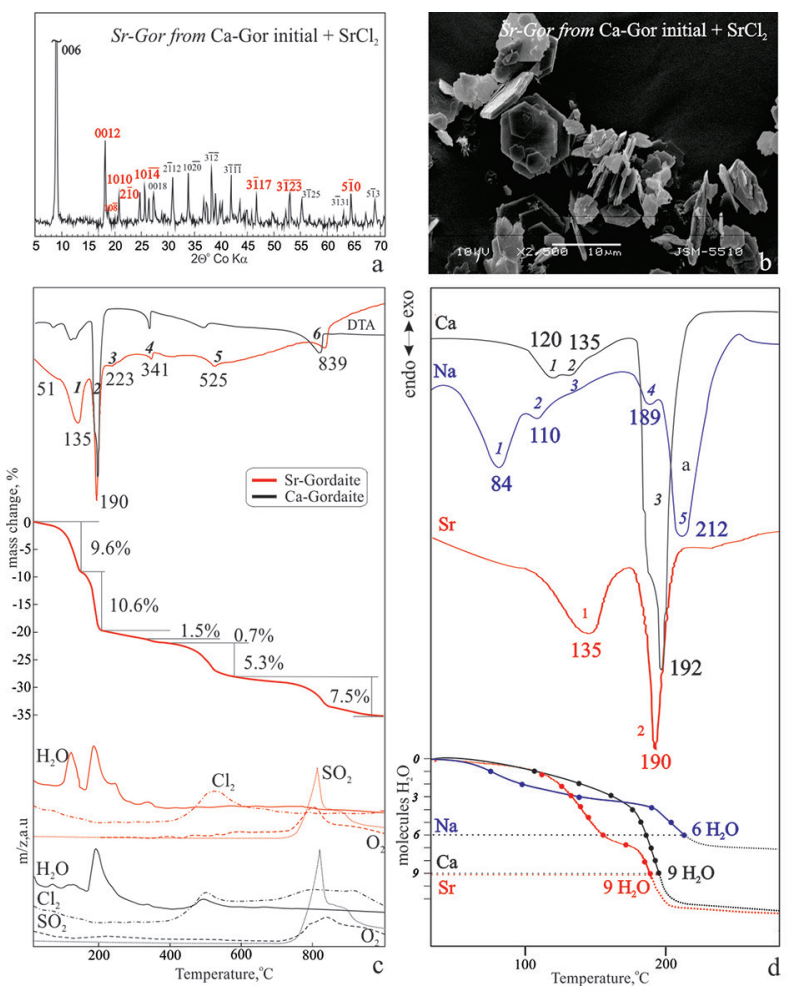

Fig. 1. Characteristic PXRD (a) and SEM (b) data of Sr-gordaite obtained from Ca-gordaite; thermal analysis data of Sr-gordaite compared with Ca-gordaite (c) and gordaite dehydration behavior depending on the exchangeable cations $-\mathrm{Ca}, \mathrm{Na}$ and $\mathrm{Sr}(\mathrm{d})$.

exchanged $\mathrm{Sr}$-form of gordaite was prepared as $1 \mathrm{~g}$ powder sample of $\mathrm{Na}$ or $\mathrm{Ca}$ gordaite was dispersed in $20 \mathrm{ml}$ of $1 \mathrm{M} \mathrm{SrCl}_{2}$ at $20^{\circ} \mathrm{C}$ for 2 to 4 days with periodic stirring, after which the sample was filtered by washing three times with distilled water and dried at room temperature.

Thermal decomposition processes were monitored by the DTA-TG method. These thermal analyses were carried out on apparatus SETSYS2400, Evolution, SETARAM at the following conditions: a static air atmosphere, with a heating rate of $10{ }^{\circ} \mathrm{C} \min ^{-1}$ and $10-15 \mathrm{mg}$ sample mass. Simultaneous analysis of the evolved gases was performed via mass spectrometry (MS) using an OmniStar apparatus.

The identification and characterization of the initial sample and the products of its thermal decomposition were carried out with X-ray powder diffraction (XRD) and Scanning electron microscopy (SEM). XRD was performed by TuR M62 diffractometer using Co Ka radiation $(1.79026 \AA)$ in the $2^{\circ} \Theta$ range $4-80^{\circ}$, step scan size $0.02^{\circ}$, counting time $2 \mathrm{~s}$ per step. SEM-EDS was carried out on apparatus JEOL - model JSM6010PLUS/LA, $20 \mathrm{kV}$ accelerating voltage, and spot size $65 \mathrm{~nm}$.

\section{Results and discussion}

Characteristic of Sr-gordaite: The powder X-ray diffraction analysis of the cation-exchanged sample shows that the experimentally obtained $\mathrm{Sr}$ product owns a powder diffraction pattern similar to that of Ca-form of gordaite (Fig. 1a). The analysis of XRD data reveals some differences caused by the substitution of the interlayer $\mathrm{Ca}^{2+}$ by $\mathrm{Sr}^{2+}$. According to the differences in both the size and weight of $\mathrm{Sr}^{2+}$ and $\mathrm{Ca}^{2+}$, a slightly higher value of the first basal reflex $\mathrm{d}_{006}=11.7 \AA$ and noticeable differences in the intensity ratios were observed (Fig. 1 a). The higher value of the $\mathrm{d}_{006}$ is directly affected by the larger ionic radius of $\mathrm{Sr}^{2+}(1.20 \AA)$ compared to that of $\mathrm{Ca}^{2+}(1.04 \AA)$, while the observed intensity differences are in correlation to the larger atomic scattering factor of $\mathrm{Sr}^{2+}$ compared to that of $\mathrm{Ca}^{2+}$. The formation of a pure strontium form of gordaite is confirmed by data from EDS analysis, which gives the chemical formula $\mathrm{SrZn}_{8}(\mathrm{OH})_{12}\left(\mathrm{SO}_{4}\right)_{2} \mathrm{Cl}_{2} \cdot \mathrm{xH}_{2} \mathrm{O}$. The SEM image shows complete preservation of the crystal forms of the parent Ca-gordaite without traces of dissolution and subsequent crystallization, which imply proceeding of typical ion exchange.

Thermal behavior: Data from the thermal analysis of the Sr-gordaite compared to those of the initial $\mathrm{Ca}$ -

Table 1. Thermal decomposition stages and processes of Sr-gordaite according to observed DTA effects and mass changes

\begin{tabular}{|c|c|c|}
\hline $\begin{array}{l}D T A- \\
\text { effect }\end{array}$ & $\begin{array}{c}\text { Mass change, } \\
\%\end{array}$ & Thermal decomposition reactions of Sr-gordaite \\
\hline 1 & $\begin{array}{c}9.6 \% \\
6.5 \mathrm{H}_{2} \mathrm{O}\end{array}$ & $\mathrm{SrZn}_{8}(\mathrm{OH})_{12}\left(\mathrm{SO}_{4}\right)_{2} \mathrm{Cl}_{2} \cdot 9 \mathrm{H}_{2} \mathrm{O} \stackrel{20-170^{\circ} \mathrm{C}}{\longrightarrow} \mathrm{SrZn}_{8}(\mathrm{OH})_{12}\left(\mathrm{SO}_{4}\right)_{2} \mathrm{Cl}_{2} \cdot 2.5 \mathrm{H}_{2} \mathrm{O}+6.5 \mathrm{H}_{2} \mathrm{O} \uparrow$ \\
\hline 2 & $\begin{array}{l}10.6 \% \\
7 \mathrm{H}_{2} \mathrm{O}\end{array}$ & $\begin{array}{l}\mathrm{SrZn}_{8}(\mathrm{OH})_{12}\left(\mathrm{SO}_{4}\right)_{2} \mathrm{Cl}_{2} \cdot 2.5 \mathrm{H}_{2} \mathrm{O} \stackrel{170-260^{\circ} \mathrm{C}}{\longrightarrow} 0.5 \mathrm{Zn}_{3}(\mathrm{OH})_{2}\left(\mathrm{SO}_{4}\right)_{2}+2 \beta-\mathrm{Zn}(\mathrm{OH}) \mathrm{Cl}+4.5 \mathrm{ZnO}+ \\
\mathrm{SrSO}_{4}+7 \mathrm{H}_{2} \mathrm{O} \uparrow\end{array}$ \\
\hline 3 & $\begin{array}{l}1.5 \% \\
1 \mathrm{H}_{2} \mathrm{O}\end{array}$ & $\begin{array}{l}0.5 \mathrm{Zn}_{3}(\mathrm{OH})_{2}\left(\mathrm{SO}_{4}\right)_{2}+2 \beta-\mathrm{Zn}(\mathrm{OH}) \mathrm{Cl}+4.5 \mathrm{ZnO}+\mathrm{SrSO}_{4} \stackrel{260-380^{\circ} \mathrm{C}}{\longrightarrow} 0.5 \mathrm{Zn}_{3}(\mathrm{OH})_{2}\left(\mathrm{SO}_{4}\right)_{2}+ \\
\mathrm{SrSO}_{4}+\mathrm{ZnCl}_{2}+5.5 \mathrm{ZnO}+1 \mathrm{H}_{2} \mathrm{O} \uparrow\end{array}$ \\
\hline 4 & $\begin{array}{c}0.7 \% \\
0.5 \mathrm{H}_{2} \mathrm{O}\end{array}$ & $\begin{array}{l}0.5 \mathrm{Zn}_{3}(\mathrm{OH})_{2}\left(\mathrm{SO}_{4}\right)_{2}+\mathrm{ZnCl}_{2}+4.5 \mathrm{ZnO}+\mathrm{SrSO}_{4} \stackrel{380-400^{\circ} \mathrm{C}}{\longrightarrow} 0.5 \mathrm{Zn}_{3} \mathrm{O}\left(\mathrm{SO}_{4}\right)_{2}+\mathrm{SrSO}_{4}+\mathrm{ZnCl}_{2}+ \\
5.5 \mathrm{ZnO}+0.5 \mathrm{H}_{2} \mathrm{O} \uparrow\end{array}$ \\
\hline 5 & $\begin{array}{l}5.3 \% \\
0.9 \mathrm{Cl}_{2}\end{array}$ & $\begin{array}{l}0.5 \mathrm{Zn}_{3} \mathrm{O}\left(\mathrm{SO}_{4}\right)_{2}+\mathrm{SrSO}_{4}+\mathrm{ZnCl}_{2}+5.5 \mathrm{ZnO} \stackrel{400-700^{\circ} \mathrm{C}}{\longrightarrow} 0.5 \mathrm{Zn}_{3} \mathrm{O}\left(\mathrm{SO}_{4}\right)_{2}+6.5 \mathrm{ZnO}+\mathrm{SrSO}_{4}+ \\
\mathrm{Cl}_{2} \uparrow\end{array}$ \\
\hline 6 & $\begin{array}{c}7.5 \% \\
1.0 \mathrm{SO}_{2} \\
0.5 \mathrm{O}_{2}\end{array}$ & $0.5 \mathrm{Zn}_{3} \mathrm{O}\left(\mathrm{SO}_{4}\right)_{2}+6.5 \mathrm{ZnO}+\mathrm{SrSO}_{4} \stackrel{700-100{ }^{\circ} \mathrm{C}}{\longrightarrow} 8 \mathrm{ZnO}+\mathrm{SrSO}_{4}+\mathrm{SO}_{2} \uparrow+0.5 \mathrm{O}_{2} \uparrow$ \\
\hline
\end{tabular}


gordaite are presented in Fig. 1 (c). In the low-temperature region for Sr-gordaite $\left(20-170{ }^{\circ} \mathrm{C}\right)$ a process of dehydration takes place with the realization of endo-effect 1 according to the registered mass losses (Fig. $1 \mathrm{c}$, Table 1). The dehydration is partial as $6.5 \mathrm{H}_{2} \mathrm{O}$ molecules are released at that time. The second endothermic event takes place in a narrow temperature range of $170-260{ }^{\circ} \mathrm{C}$, as the mass losses registered by TG are associated with the release of other $7 \mathrm{H}_{2} \mathrm{O}$ molecules, which corresponds to the end of dehydration and the beginning of dehydroxylation. The course of this first stage of dehydroxylation causes the destruction of the gordaite hydroxide layer and the formation of secondary zinc hydroxy-salts $-\mathrm{Zn}_{3}(\mathrm{OH})_{2}\left(\mathrm{SO}_{4}\right)_{2}, 2 \beta-\mathrm{Zn}(\mathrm{OH})$ $\mathrm{Cl}$ and $\mathrm{SrSO}_{4}$. The process of dehydroxylation of the system ends within effects 3 and $4\left(260-400{ }^{\circ} \mathrm{C}\right)$ with the sequential dehydroxylation of $2 \beta-\mathrm{Zn}(\mathrm{OH}) \mathrm{Cl}$ and $\mathrm{Zn}_{3}(\mathrm{OH})_{2}\left(\mathrm{SO}_{4}\right)_{2}$ (Table 1). Within endo-effect 5 (400$700{ }^{\circ} \mathrm{C}$ ) the whole amount of $\mathrm{Cl}_{2}$ in the structure of $\mathrm{Sr}$-form is released, and in the last temperature region (700-1000 ${ }^{\circ} \mathrm{C}$ ) within endo-effect $6, \mathrm{SO}_{2}$ and $\mathrm{O}_{2}$ are released from $\mathrm{Zn}_{3} \mathrm{O}\left(\mathrm{SO}_{4}\right)_{2}$, while $\mathrm{SrSO}_{4}$ remains stable at that temperatures.

Data from TG and DTA-MS analyzes show that in both cases, the observed processes of thermal decomposition are dehydration, dehydroxylation, and release of $\mathrm{SO}_{2}, \mathrm{O}_{2}$, and $\mathrm{Cl}_{2}$ occurring in similar temperature ranges. However, the analysis of the thermal data shows a clear influence of the $\mathrm{Sr}^{2+}$ on the course of the individual processes and the products of thermal decomposition.

The different cationic forms of the gordaite differ primarily in the content of the interlayer. The features (valence, size, ionic potential) caused different amounts and coordination of water molecules. The two forms ( $\mathrm{Sr}$ and $\mathrm{Ca}$ ) in the interlayer space have $9 \mathrm{H}_{2} \mathrm{O}$ molecules coordinating the interlayer cation. However, the leaving of the interlayer molecules in the low-temperature region in the two forms takes place in different ways. The dehydration of the Srform in the $20-170{ }^{\circ} \mathrm{C}$ region is related to evolving of $6.5 \mathrm{H}_{2} \mathrm{O}$ molecules while for the Ca-form in the same region only $3.6 \mathrm{H}_{2} \mathrm{O}$ molecules are released. It could be assumed, that the facilitation of the water release for the Sr-form at the beginning of the process is due to the lower ionic potential of the $\mathrm{Sr}^{2+}$ compared to that of $\mathrm{Ca}^{2+}$ (Fig. 1 d). The comparison of the dehydration of gordaite forms with divalent interlayer cations $\mathrm{CSr}^{2+}$ and $\mathrm{Ca}^{2+}$ ) with that of gordaite, in which the compensating cation is $\mathrm{Na}^{+}$, shows the influence of valence on the process. In the $\mathrm{Sr}$ (or $\mathrm{Ca}$ )-gordaite this process occurs faster and in a narrower temperature range (20 $200{ }^{\circ} \mathrm{C}$ ) compared to the Na-gordaite $\left(20-215^{\circ} \mathrm{C}\right)$, although the hydrated coordination of $\mathrm{Sr}^{2+}\left(\right.$ or $\left.\mathrm{Ca}^{2+}\right)$ is of $9 \mathrm{H}_{2} \mathrm{O}$ molecules while the $\mathrm{Na}^{+}$is coordinated with $6 \mathrm{H}_{2} \mathrm{O}$ molecules. This is due to the presence of two $\mathrm{Na}$-hydrate complexes in the interlayer space, as opposed to one Ca-hydrate complex.

The dehydroxylation process is also influenced by the interlayer cation. The first stage of dehydroxylation of gordaites is characterized by the destruction of the hydroxide layer and the formation of various secondary phases. In contrast to the Ca-gordaite, in which after the process of the first stage of dehydroxylation both $\mathrm{Zn}$ and $\mathrm{Ca}$ secondary hydroxide phases are formed $\left(\mathrm{Zn}_{3}(\mathrm{OH})_{2}\left(\mathrm{SO}_{4}\right)_{2}, 2 \beta-\mathrm{Zn}(\mathrm{OH}) \mathrm{Cl}\right.$ and $\left.\mathrm{Ca}(\mathrm{OH})_{2}\right)$, in the Sr-gordaite, the $\mathrm{Sr}^{2+}$ directly forms celestine $\left(\mathrm{SrSO}_{4}\right)$ without passing through the hydroxide phase. This composition of the residual material also appears to affect the dehydroxylation of the secondary Zn-hydroxy-salt compounds as well as the release of $\mathrm{Cl}$ from the structure. In Sr-gordaite the dehydroxylation of the secondary Zn hydroxy-salt phases is distinguished, being carried out differently in two stages. The evolving of $\mathrm{Cl}_{2}$ from the $\mathrm{Sr}$-gordaite is one stage process, unlike the case of the $\mathrm{Ca}$-form, where the separation of $\mathrm{Cl}_{2}$ is a continuing process.

In conclusion: the thermal behavior of Sr-gordaite was studied for the first time: (i) similarity was found with Ca-gordaite in terms of processes, type, and amount of volatiles released; (ii) differences were also found concerning the temperature correspondence of the volatiles evolving and the type of thermal decomposition products. The role and the influence of the exchangeable cations $\left(\mathrm{Na}^{+}, \mathrm{Ca}^{2+}\right.$, or $\left.\mathrm{Sr}^{2+}\right)$ on the dehydration of the interlayer in the gordaite type structure were also established.

Acknowledgements: This work was supported by the Bulgarian Ministry of Education and Science under the National program "Young scientists and postdoctoral students".

\section{References}

Adiwidjaja, G., K. Frise, K.-H. Klaska, J. Schlüter. 1997. The crystal structure of gordaite $\mathrm{NaZn}_{4}\left(\mathrm{SO}_{4}\right)(\mathrm{OH})_{6} \mathrm{Cl} \cdot 6 \mathrm{H}_{2} \mathrm{O}$. - Z. Kristallogr., 212, 704-707; https://doi.org/10.1524/ zkri.1997.212.10.704.

Bear, I. J., I. E. Gray, I. C. Madsen, I. E. Newnham, L. J. Rogers. 1986. Structures of basic zinc sulfates $3 \mathrm{Zn}(\mathrm{OH})_{2} \cdot \mathrm{ZnSO}_{4} \cdot \mathrm{mH}_{2} \mathrm{O}, \mathrm{m}=3$ and 5. - Acta Crystallogr., B 42, 32-39; https://doi.org/10.1107/S0108768186098622.

Bear, I. J., I. E. Gray, I. E. Newnham, L. J. Rogers. 1987. The $\mathrm{ZnSO}_{4} .3 \mathrm{Zn}(\mathrm{OH})_{2}-\mathrm{H}_{2} \mathrm{O}$ system. I. Phase formation. - Aust. J. Chem., 40, 539-556; https://doi.org/10.1071/CH9870539.

Maruyama, S. A., F. Krause, S. R. T. Filho, A. A. Leitão, F. Wypych. 2017. Synthesis, cation exchange and dehydration/rehydration of sodium gordaite: $\mathrm{NaZn}_{4}(\mathrm{OH})_{6}\left(\mathrm{SO}_{4}\right)$ $\mathrm{Cl} \cdot 6 \mathrm{H}_{2} \mathrm{O}$. - Appl. Clay Sci., 146, 100-105; https://doi. $\operatorname{org} / 10.1016 /$ j.clay.2017.05.029.

Moezzi, A., M. B. Cortie, A. M. McDonagh. 2013. Zinc hydroxide sulfate and its transformation to crystalline zinc oxide. - Dalton Trans., 42, 14432-14437; https://doi. org/10.1039/c3dt51638e.

Santana, J., B. M. Fernández-Pérez, J. Morales, H. C. Vasconcelos, R. M. Souto, S. González. 2012. Characterization of the corrosion products formed on zinc in archipelagic subtropical environments. - Int. J. Electrochem. Sci., 7, $12730-12741$.

Sillitoe, R. H. 2005. Supergene oxidized and enriched porphyry copper and related deposits. - Econom. Geol., 100, 723760; https://doi.org/10.5382/AV100.22.

Stanimirova, Ts., N. Petrova, G. Kirov. 2016 Thermal decomposition of zinc hydroxy-sulfate-hydrate minerals. - $J$. Thermal Anal. and Calorimetry, 123, 85-96; https://doi. org/10.1007/s10973-016-5325-x. 